\title{
PRECIPITATION SOLVENTS FOR RNA EXTRACTION OF DENGUE VIRUS TYPE 3: DIMETHYLFORMAMIDE, ETHYLENEDIAMINTETRAACETIC ACID, AND ULTRAPURE $\mathrm{H}_{2} \mathrm{O}$
}

\author{
Rizqidhana Juliana Putri ${ }^{1}$, Teguh Hari Sucipto ${ }^{2 *}$, Harsasi Setyawati ${ }^{1}$, Siti Churrotin ${ }^{2}$, \\ Ilham Harlan Amarullah ${ }^{2}$, Puspa Wardhani ${ }^{2}$, Aryati $^{2}$, Soegeng Soegijanto ${ }^{2}$ \\ ${ }^{1}$ Department of Chemistry, Faculty of Science and Technology, Universitas Airlangga, Surabaya \\ ${ }^{2}$ Dengue Study Group, Institute of Tropical Disease, Universitas Airlangga, Surabaya \\ *Corresponding author: teguhharisucipto@staf.unair.ac.id
}

Received 20 October 2018

Accepted 20 December 2018

\begin{abstract}
Dengue is a disease caused by a virus from the family Flaviviradae, carried by a female mosquito of Aedes aegypti species. Dengue fever is widespread in the tropic areas. It caused by rainfall, temperature and unplanned urbanization. According to the ministry of health, almost all provinces in Indonesia are endemic areas of dengue fever. In 2014, up to mid-December Dengue Hemorrhagic Fever (DHF) patients in 34 provinces in Indonesia are 71,668 people and 641. This figure is lower than the previous year, 2013 with 112,511 people and 871 deaths . This disease consists of four types of serotypes, namely DENV-1, DENV-2, DENV-3, and DENV-4. This disease can be identified using a variety of methods, one of the method is Reverse Transcription - Polymerase Chain Reaction (RTPCR) method. This study aims to determine the ability of Dimethylformamide (DMF), Ethylenediamintetraacetic Acid (EDTA), and Ultrapure $\mathrm{H}_{2} \mathrm{O}$ as the substitute of Ethanol for precipitation in RNA extraction process. The sample used in this research obtained from Surabaya. RNA extraction itself can be done by using a special kit for RNA extraction. In Reverse Transcription - Polymerase Chain Reaction method, first RNA is extracted and then transcribed back (Reverse Transcription) which then form cDNA that later will be amplified by using PCR method. In this study used specific primers for dengue virus type 3 (DENV-3). The results of this study show that DMF, EDTA, and Ultrapure $\mathrm{H}_{2} \mathrm{O}$ can be used as the substitute of Ethanol for precipitation on RNA extraction. The result is evidenced by the formation of viral DNA bands on gel electrophoresis results.
\end{abstract}

Keywords : RNA, Precipitation Solvent, DMF, EDTA, Ultrapure $\mathrm{H}_{2} \mathrm{O}$

\section{Introduction}

Dengue is considered as the most prevalent arthropod-borne viral disease in the world with significant burden to people in tropical and subtropical regions (Bhatt et al., 2013). The Dengue virus comprise four serotypes, designated as DENV-1 , DENV-2 , DENV-3 , and DENV-4 (OhAinle et al., 2011). They are transmitted by Aedes aegypti and Aedes albopictus mosquitoes and belong to the family Flaviviridae and genus Flavivirus (Weaver et al., 2010; Halstead, 2008).
Infection with any of those serotypes causes a mild and self-limiting febrile illness (classical dengue fever (DF)); a few cases are severely developing to lifethreatening dengue hemorrhagic fever (DHF) and dengue shock syndrome (DSS). Dengue fever (DF) is an acute febrile viral disease frequently presenting with headaches, bone or joint and muscular pains, rash and leukopenia as symptomps. Dengue hemorrhagic fever (DHF) is characterized by four major clinical manifestations: high fever, 
hemorrhagic phenomena, often with hepatomegaly and, in severe cases, signs of circulatory failure. Such patients may develop hypovolaemic shock resulting from plasma leakage. This is called dengue shock syndrome (DSS) and can be fatal (WHO, 2009).

There is a rapid method to identify the Flavivirus in the acute-phase sera of febrile patients, or from cultured virus samples, and the spesific identifications of dengue serotype using a Reverse transcription - Polymerase chain reaction (RT-PCR) method. Because dengue virus belongs to RNA virus, to detect specific RNA molecules, RNA molecules must first be converted to DNA molecules for PCR detection. The process is started with isolation of RNA. The isolation of RNA begin with cellulars lysis mediated by buffers those consisting harsh chaotropic agents and those that gently solubilize the plasma membrane while maintaining nuclear and other organelle integrity (Robert and Farell, 2010). Continue with precipitation process and the last is purification. The commonly used method for precipitating RNA is the ethanol precipitation. This method is accomplished by reacting together salt (ammonium acetate, sodium acetate, etc.) with ethanol and adding the mixture to the solution containing RNA. Ammonium acetate is efficient for ethanol precipitating small and larger RNAs, but does not precipitate nucleotides, making it a good candidate for the purification of RNAs after reactions. Also, ammonium acetate can inhibit T4 polynucleotide kinase, so it is not a good choice for purifying RNAs that will be phosphorylated following purification. Sodium acetate is highly efficient at ethanol precipitating nucleic acids, and as a result also precipitated nucelotides, DNA, and small RNA fragments. However, sodium acetate is the most versatile salt because in addition to being highly efficient precipitating all nucleic acids, it does not inhibit many of the reactions that are often performed with purified RNAs (Walker and Lorsch, 2013). In this study there are several kinds of solvent, such as DMF, EDTA, and ultra pure water, which can be used as the substitute of the commonly used solvents to precipitate RNA. This study shows good results which can be considered in the future for the development of several RNA extraction methods.

\section{Material and Methods \\ Material \\ Dengue virus type 3 (DENV-3) obtained from Surabaya (Genbank:} AB915377), Dimethylformamide (DMF) (Merck, Germany), Ethanol 96\% (Merck, Germany), Ethylenediamintetraacetic Acid (EDTA) (Merck, Germany), Ultrapure Water (Invitrogen, USA). RNA isolation (QIAamp Mini Kit) supplied by Qiagen from USA. Master mix PCR supplied by Promega from USA, and reagent for RT-PCR supplied by Invitrogen from Germany. Nuclease Free Water (NFW) by Qiagen from USA , Ethidium bromide (Merck, Germany), TAE buffer (Promega, USA), Agarose (Promega, USA), primers as shown in the Table 1.

Table 1. Oligonucleotide primers used to amplify and type dengue viruses (Lanciotti et al., 1992)

\begin{tabular}{c|l|c|c}
\hline Primer & Sequence & Genome position & $\begin{array}{c}\text { Size of Amplified DNA } \\
\text { (bp) and Primers }\end{array}$ \\
\hline D1 & 5'-tcaatatgctgaaacgcgcgagaaaccg-3' & $134-161$ & 511
\end{tabular}




\begin{tabular}{c|l|l|c} 
D2 & 5-'ttgcaccaacagtcaatgtcttcaggttc- 3' & $616-644$ & 511 \\
\hline TS1 & 5'-cgtctcagtgatccggggg-3' & $568-586$ & 482 (D1 and TS1) \\
\hline TS2 & 5'-cgccacaagggccatgaacag-3' & $232-252$ & 119 (D1 and TS2) \\
\hline TS3 & 5'-taacatcatcatgagacagagc-3' & $400-421$ & 290 (D1 and TS3) \\
\hline TS4 & 5'-ctctgttgtcttaaacaagaga-3' & $506-527$ & 392 (D1 and TS4) \\
\hline
\end{tabular}

\section{RNA Isolation}

The RNA used in this research was isolated from Vero infected cells. Mix $0.56 \mathrm{~mL}$ Buffer AVL with $5.6 \mu \mathrm{L}$ carrier RNA. Mix them well by pipetting the mixture. After that, take $560 \mu \mathrm{L}$ of the Buffer AVL that contain carrier RNA and mix it with the sample of Vero infected cells. Then mix the solutions using the Vortex for about $15 \mathrm{~s}$. Incubate the solution at room temperature for ten minutes. $560 \mu \mathrm{L}$ Ethanol $96 \%$ then added to the solutions. $630-\mu \mathrm{L}$ of the solutions transferred to mini column QiAamp and centrifuged at $8,000 \mathrm{rpm}$ for a minute. The aqueous phase then removed and an equal volume of the previous solution is added to the column. After that, centrifuged the solution at $8,000 \mathrm{rpm}$ for a minute and the aqueous phase was removed. The supernatant then washed with $500 \mu \mathrm{L}$ of AW 1 buffer and centrifuged as above. The aqueous phase that formed was removed and continued with adding $500 \mu \mathrm{L}$ of AW 2 buffer. The solutions then centrifuged for 3 minutes at $14,000 \mathrm{rpm}$. The column is transferred into a new tube and the supernatant is eluted with $40 \mu \mathrm{L}$ of AVE buffer. Then centrifuged for one minute at $8,000 \mathrm{rpm}$. The aqueous phase that formed eventually contain the pure RNA. The final result then stored in a $-80^{\circ} \mathrm{C}$ refrigerator. In this research there was a modification of the precipitation solvent. Precipitation usually done by using Ethanol, however in this research the Ethanol was substituted with Dimethylformamide (DMF) Ethylenediamintetraacetic Acid (EDTA), and sterilized $\mathrm{H}_{2} \mathrm{O}$. The purity and concentration of RNA result then determined by nanodrop spectrophotometry with absorbance 260 to 280 ratio $\left(\mathrm{A}_{260} / \mathrm{A}_{280}\right)$ and 260 to 230 ratio $\left(\mathrm{A}_{260} / \mathrm{A}_{230}\right)$.

\section{Reverse Transcription ( $R T$ )}

The Reverse Transcription (RT) process is started with mixing the dNTP $10 \mu \mathrm{M} 1-\mu \mathrm{L}$; primer $1-\mu \mathrm{L}$; Nuclease free water (NFW) $7-\mu \mathrm{L}$ with RNA $5-\mu \mathrm{L}$. Then put the tube which has been contained with the mixture inside the Thermo cycler. Incubate for 5 minutes at $65^{\circ} \mathrm{C}$. After that, mix 5× FS Buffer 4- $\mu \mathrm{L}$; DTT $0.1 \mathrm{M} 1-\mu \mathrm{L}$; Superscript III $0.5-\mu \mathrm{L}$ and RNase out $0.5-\mu \mathrm{L}$. Mix them well, then add the mixture to the tube that has been processed before. Put the tube into the thermo cycler and incubate at $55^{\circ} \mathrm{C}$ for 50 minutes and at $85^{\circ} \mathrm{C}$ for 5 minutes.

\section{DNA Amplification by Polymerase Chain Reaction ( PCR )}

A $5-\mu \mathrm{L}$ portion of the cDNA result from the RT process mixed with $20-\mu \mathrm{L}$ volumes mixture containing the following components : $12.5-\mu \mathrm{L}$ Master Mix PCR, Nuclease free water $5.5-\mu \mathrm{L}$, and $2-\mu \mathrm{L}$ primer. The solutions then mixed with Vortex for about $15 \mathrm{~s}$ and centrifuged at $8,000 \mathrm{rpm}$ for a minute. After that, put the tube into the thermo cycler that has been programmed the PCR process.

\section{Agarose Gel Electrophoresis}

A $5-\mu \mathrm{L}$ portion of isolated DNA is mixed with $1-\mu \mathrm{L}$ loading dye and $4-\mu \mathrm{L}$ of Nuclease free water. The solutions then dropped inside the lane on the agarose gel and run with $3-\mu \mathrm{L}$ of marker at 100 Volt for 30 minutes. Continued with the gel 
stained in Et-Br (Ethidium Bromide) solutions for 20-30 minutes. After that,

\section{Results and Discussion}

In this report, there will be an explanation about the use of substitute solvents to precipitate RNA within the RNA extraction process. The Dengue virus comprise four serotypes, designated as DENV-1, DENV-2, DENV-3 and DENV-4. The virus serotype can be identified using several methods and the method used in this study is the PCR method. The Reverse Transcription Polymerase Chain Reaction (RT-PCR) method used in this study is a rapid method to identfy and typing of Dengue virus. The sample used in this study is obtained from Surabaya. The identification test begin with the RNA extraction, continued with RT-PCR process and ended with analysis using the agarose gel electrophoresis.

RNA extraction begin with the serum sample that processed using the lysis buffer which then continued with the precipitation process. RNA that formed from the precipitation process then purified and eluted using the solvent and method as described above, until obtained the high pure RNA that will be processed by RT-PCR afterwards. The result from the gel is put on an ultraviolet transilluminator to visualize the bands.

RT-PCR process is cDNA which will be used to identify the Dengue virus serotype. In this study, there will be some modification about the precipitation solvents. The commonly used precipitation solvent in RNA extraction, which is Ethanol, will be substituted with Dimethylformamide (DMF), Ethylenediamintetraacetic Acid (EDTA), and ultra pure water. The substitute solvents showed a good result of the precipitation process, which indicated by the appearance of the DNA bands (as shown in Figure 1). The appearance of the DNA bands showed that the RNA is formed well by the precipitation process. With the existing results, it can be said that DMF, EDTA, and ultra pure water can replace the work of Ethanol as a precipitation solvent. As well as Ethanol, DMF, EDTA, and ultra pure water are polar solvents that have similar solubilizing capabilities, making it possibles to precipitate the RNA. The arising DNA bands shown in the Figure.1 is the proof that the serum sample is positive dengue virus. Positive control that used is DENV-3 (290 bp).

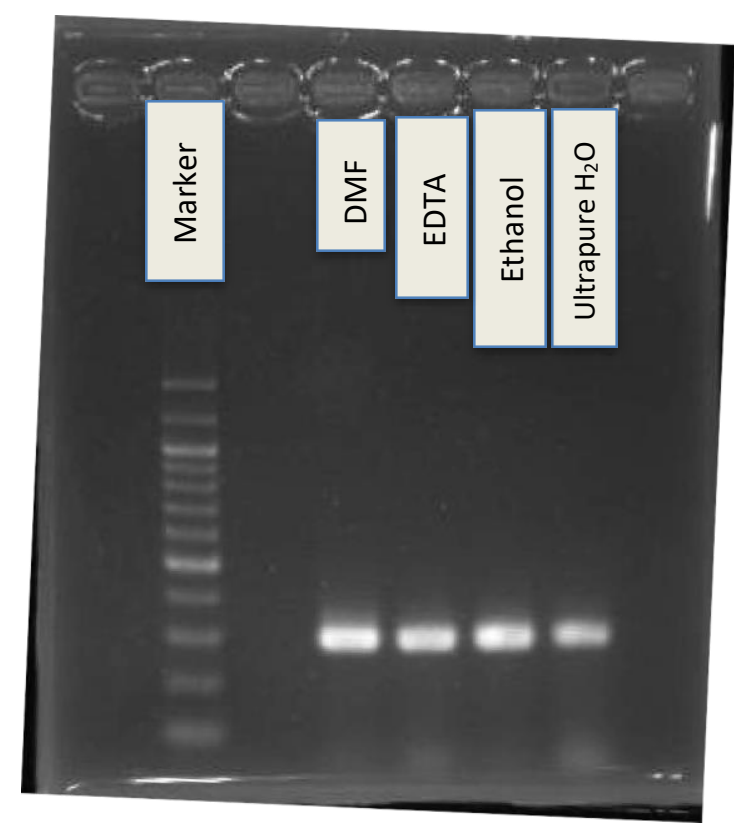

Figure 1. Results of Electrophoresis of cDNA from PCR process 
The purity and concentration of RNA result then determined by using the nanodrop spectrophotometry with absorbance 260 to 280 ratio $\left(\mathrm{A}_{260} / \mathrm{A}_{280}\right)$ and 260 to 230 ratio $\left(\mathrm{A}_{260} / \mathrm{A}_{230}\right)$. The absorbance data showed in Table 2 .

Table 2. The data result of NanoDrop Spectrophotometry for RNA samples

\begin{tabular}{lcc}
\hline \multicolumn{1}{c}{ Sample } & A260/280 nm & A260/A230 nm \\
\hline DENV3 - DMF & 3.18 & 0.46 \\
DENV3 - EDTA & 3.18 & 0.55 \\
DENV3 - Ethanol 96\% & 2.88 & 0.69 \\
DENV3 - Ultrapure $\mathrm{H}_{2} \mathrm{O}$ & 2.86 & 0.19 \\
\hline
\end{tabular}

The purity and concentration of RNA and DNA samples are determined readily by taking advantage of the ability of nucleic acids to absorb UV light, with an absorbance maximum at $260 \mathrm{~nm}$. A pure sample of RNA has an $\mathrm{A}_{260} / \mathrm{A}_{280}$ ratio of $2.0 \pm 0.1$ and the $\mathrm{A}_{260} / \mathrm{A}_{230}$ ratio should be greater than 2.0 and less than 2.4. Variations outside this range generally indicate contaminants (Robert and Farell, 2010). The results show that none of the sample have ratio of $\mathrm{A}_{260} / \mathrm{A}_{280}$ less than 2.0 and it indicates the absence of contamination. But, at $\mathrm{A}_{260} / \mathrm{A}_{230}$ all the sample show up the ratio is less than 2.0 which means that there are organic compound contamination.

\section{Conclusion}

Sample suspected of Dengue Hemorrhagic Fever (DHF) which is obtained from Surabaya detected as Dengue virus type 3 (DENV-3). From the quantitative measurement of RNA using

\section{References}

Bhatt S., Gething P.W., Bardy O.J., Messina J.P., Farlow A.W., Moyes C.L., Drake J.M., Brownstein J.S., Hoen A.G., Sankoh O., Myers M.F., George D.B., Jaenisch T., Wint G.R.W., Simmons C.P., Scott T.W., Farrar J.J., and Hay S.I., The Global Distribution and Burden of Dengue. Nature, 496, 504-507(2013) nanodrop spectrophotometry with an absorbance of 260/280 ratio and 260/230 ratio, also the results of DNA bands in agarose gel electrophoresis from RT-PCR process, it can be concluded that Dimethylformamide

(DMF), Ethylenediamintetraacetic Acid (EDTA), and Ultrapure water can be the substituted for Ethanol as a precipitation solvents within the RNA extraction.

\section{Acknowledgement}

Thanks to Institute of Tropical Disease Airlangga Univesity for the opportunity to join the internship and undertake this research in the Dengue Laboratory, Institute of Tropical Disease Universitas Airlangga, Department of Chemistry, Faculty of Science and Technology Universitas Airlangga and Japan Initiative for Global Research network on Infectious Disease (J-GRID).

Halstead S.B., Dengue Virus-Mosquito Interactions. Annual Review of Entomology, 53, 273-91(2008)

Lanciotti R.S., Calisher, C.H., Gubler D.J., Chang, G.J., and Vorndam A.V., Rapid Detection and Typing of Dengue Viruses from Clinical Samples by Using Reverse Transcriptase-Polymerase Chain 
Reaction. Journal of Clinical Microbiology, 30(3), 545-551(1992)

OhAinle M., Balmaseda A., Macalalad A.R., Tellez Y., Zody M.C., Saborio S., Nuñez A., Lennon N.J., Birren B.W., Gordon A., Henn M.R., and Harris E., Dynamics of Dengue Disease Severity Determined by The Interplay Between Viral genetics and Serotype-Specific Immunity. Science Translational Medicine, 3(114), 114ra128(2011)

Robert E., Farell Jr., RNA Methodologies. A Laboratory Guide for Isolation and Characterization. $4^{\text {th }}$ Edition. Elsevier Academic Press, Burlington, (2010)
Walker S.E., Lorsch J., RNA PurificationPrecipitation Methods. Methods in Enzymology, Vol 530. Department of Biophysics and Biphysical Chemistry, Johns Hopkins University School of Medicine, Baltimore, MD, USA, p. 337-343 (2013)

Weaver S.C., and Reisen W.K., Present and Future Arboviral Threats. Antiviral Research, 85(2), 32845(2010)

World Health Organization, Dengue: Guidelines for Diagnosis, Treatment, Prevention and Control. In : Dengue : Guidelines for Diagnosis, Treatment, Prevention and Control: New Edition, 2009 ${ }^{\text {th }}$ Geneva, (2009). 